JAMP: Jurnal Adminitrasi dan Manajemen Pendidikan

Volume 1 Nomor 1 Maret 2018, Hal : 29-36

Tersedia Online di http://journal2.um.ac.id/index.php/jamp/

ISSN $x x x x-x x x x$ (online)

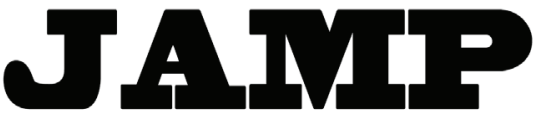

\title{
ANALISIS TINGKAT KUALITAS LAYANAN REGISTRASI ADMINISTRASI
}

\author{
Atanasius Cahyadi Ngelon \\ Burhanuddin \\ Wildan Zulkarnain
}

email: atanasius95@gmail.com

Universitas Negeri Malang, Jl. Semarang No. 5 Malang 65145

\begin{abstract}
The purpose of the study is: to find out how high the level of quality of administrative registration services in the Faculty of Education Sciences State University of Malang. The quality of services provided is determined by the following factors, namely: Reliability, Responsiveness, Assurance, Empathy, and Physical Evidence. The research method is: using a quantitative approach with descriptive exploratory design. Selection of sample members using random sampling technique. The results of research are: The quality of administrative registration service in the Faculty of Education Science State University of Malang is at a level or high category. In addition, the results of the measurement of the five factors of service quality are also each in the high category.
\end{abstract}

Key Word: Service Quality, Administrative Registration Services.

\begin{abstract}
Abstrak: Tujuan penelitian adalah: untuk mengetahui seberapa tinggi tingkat kualitas layanan registrasi administrasi di Fakultas Ilmu Pendidikan Universitas Negeri Malang. Adapun kualitas jasa yang diberikan ditentukan oleh faktor-faktor berikut, yaitu: Kehandalan, Daya Tanggap, Jaminan, Empati, dan Bukti Fisik. Metode penelitian adalah: menggunakan pendekatan kuantitatif dengan desain deskriptif eksploratori. Pemilihan anggota sampel menggunakan teknik random sampling. Hasil penelitian adalah: Kualitas layanan registrasi administrasi di Fakultas Ilmu Pendidikan Universitas Negeri Malang berada pada tingkat atau kategori tinggi. Selain itu, hasil pengukuran kelima faktor kualitas layanan juga masingmasing berada pada kategori tinggi.
\end{abstract}

Kata kunci: Kualitas Layanan, Layanan Registrasi Administrasi.

Pendidikan merupakan salahsatu aspek pembangunan yang sangat dijamin pemenuhannya oleh Negara bagi seluruh rakyatnya. Hal tersebut sesuai dengan bunyi Pasal 31 Ayat1 Undang-Undang Dasar 1945, bahwa setiap warga negara berhak mendapatkan pendidikan. Berdasarkan bunyi pasal tersebut, maka setiap orang yang menjadi warga negara indonesia memiliki hak penuh untuk memperoleh layanan pendidikan yang layak melalui lembaga pendidikan dari yang dasar sampai pendidikan tinggi. Keberadaan lembaga pendidikan menjadi sangat strategis sebagai pembentuk sumber daya manusia yang berkualitas dan merupakan kunci pokok kemajuan pembangunan suatu negara, khususnya di era globalisasi ini yang erat dengan persaingan. Kualitas pendidikan yang semakin meningkat akan merambah ke aspek-aspek pembangunan lainnya dan mendukung kemajuan suatu negara. Maka dari itu, lembaga pendidikan dituntut untuk meningkatkan kinerja bagi terwujudnya tujuan tersebut. Lembaga pendidikan sebagai alat harus mampu memberikan layanan yang berkualitas bagi warga lembaga pendidikan itu sendiri.

Di era ini, kebutuhan masyarakat terhadap pendidikan semakin meningkat, khususnya pendidikan tinggi. Hal tersebut menjadikan perguruan tinggi sebagai sektor strategis yang diharapkan dapat menghasilkan sumber daya manusia yang bermutu. Keadaan persaingan yang cukup kompetitif antar 
perguruan tinggi menuntut lembaga pendidikan memperhatikan mutu pendidikan dan kelembagaan sehingga mampu serta unggul dalam persaingan tersebut. Perguruan tinggi harus melakukan langkah antisipasi guna menghadapi persaingan yang semakin kompetitif serta bertanggung jawab untuk menggali dan meningkatkan segala aspek pelayanan yang dimiliki, karena sebuah pelayanan yang dimiliki oleh lembaga tertentu akan menjadi gambaran dari kualitas lembaga tersebut, jika pelayanan yang diberikan menurut konsumen itu baik maka sebuah lembaga tersebut bisa dikatakan baik. Tapi sebaliknya jika pelayanan yang dimiliki suatu lembaga buruk maka lembaga tersebut akan dikatakan buruk. Termasuk juga pelayanan dalam sebuah lembaga pendidikan.

Daviddow dan Utal (dalam Chrisyanti, 2011: 50) menyatakan pada dasarnya pelayanan merupakan aktivitas/manfaat yang ditawarkan oleh organisasi atau perorangan kepada konsumen (customer) yang bersifat tidak berwujud dan tidak dapat dimiliki. Menurut Gronroos (dalam Ratminto dan Atik, 2009) mendefinisikan pelayanan adalah suatu aktivitas atau serangkaian aktivitas yang bersifat tidak kasat mata (tidak dapat diraba) yang terjadi akibat adanya interaksi antara konsumen dengan pegawai atau hal-hal lain yang disediakan oleh perusahaan pemberi pelayanan yang dimaksudkan untuk mencari jalan keluar terhadap permasalahan yang dihadapi konsumen/pelanggan. Lebih jauh Norman (dalam Chrisyanti, 2011: 51) memberikan karakterisitk pelayanan sebagai berikut: Pelayanan merupakan suatu produksi yang sifatnya tidak dapat diraba, berbeda dengan barang produksi lain (barang jadi atau barang industri yang berwujud). Dari pendapat para ahli di atas dapat disimpulkan bahwa pelayanan adalah aktivitas yang terjadi akibat adanya interaksi antara penyedia layanan, organisasi atau perorangan dengan pelanggan dan menghasilkan produk yang tidak dapat diraba atau kasat mata yang disebut dengan jasa. Jasa itu sendiri adalah setiap tindakan atau kegiatan yang dapat ditawarkan oleh suatu pihak kepada pihak lain yang pada dasarnya tidak berwujud dan tidak menyebabkan kepemilikan kepada sesuatu, yang dapat berhubungan dengan suatu produk fisik maupun tidak.

Kualitas pelayanan menjadi aspek penting dalam penilaian tingkat keberhasilan suatu organisasi, lembaga atau perusahaan (dalam hal ini lembaga pendidikan). Konsumen akan lebih mudah menilai baik tidaknya suatu lembaga berdasarkan pelayanan yang diterima dari proses interaksi yang terjadi dalam pemenuhan kebutuhan pelanggan itu sendiri. Zeithaml (dalam Susanto, 2014) mengemukakan bahwa kualitas pelayanan ditentukan oleh dua hal, yaitu Expected Service dan Precived Service. Konsep kualitas layanan dapat dipahami melalui perilaku konsumen dalam mencari, membeli, menggunakan, dan mengevaluasi suatu produk maupun pelayanan yang diharapkan dapat memuaskan kebutuhan mereka. Kotler (dalam Susanto, 2014) mengemukakan bahwa kepuasan pelanggan merupakan tingkat perasaan dimana seseorang menyatakan hasil perbandingan atas kinerja produk atau jasa yang diterima dan yang yang diharapkan. Dari pernyataan tersebut, dapat dikatakan bahwa kepuasan pelanggan sangat ditentukan atau diukur oleh dua hal yaitu, pelayanan seperti apa yang diharapkan pelanggan dan pelayanan seperti apa yang dirasakan oleh pelanggan. Perbandingan anatara kedua hal tersebut menjadi dasar bagi pelanggan untuk menentukan kualitas pelayanan suatu leambaga pendidikan.

Lembaga pendidikan sendiri, dalam hal ini perguruan tinggi sebagai suatu bentuk organisasi pendidikan tidak lepas dari adanya proses administrasi di dalamnya. Meskipun secara umum memiliki ciri yang sama dengan lembaga lainnya, namun pada penerapannya memiliki sistem atau tata cara pengelolaan yang berbeda dengan sistem administrasi di organisasi yang lain. Ada beberapa bagian dalam pengelolaan administrasi di perguruan tinggi yang kemudian diterapkan pada masing-masing fakultas. Beberapa sub bagian tersebut adalah Kasubag umum (sarana pra-sarana), Kasubag Akademik, Kasubag Keuangan dan Kasubag kemahasiswaan. Setiap Kasubag ini dikoordinasikan oleh Kepala Tata Usaha dan setiap sub bagian bertugas sesuai bagiannya masing-masing.

Pada penelitian ini lebih ditekankan pada sub bagian akademik. Dalam pelaksanannya sub bagian ini membidangi kegiatan-kegiatan perkuliahan seperti halnya jadwal perkuliahan, nilai, dan kegiatankegiatan kemahasiswaan yang berkaitan dengan akademik mahasiswa di lingkungan kampus. Aktivitasaktivitas pada sub bagian akademik cenderung lebih banyak sehingga melibatkan banyak pihak juga khususnya mahasiswa yang terlibat secara langsung. Melalui kegiatan-kegiatan tersebut mengakibatkan adanya interaksi yang sering terjadi antara mahasiswa dengan pegawai administrasi akademik dalam upaya memenuhi kebutuhan akademik mahasiswa tersebut. 
Kegiatan akademik sangat terkait dengan proses pembelajaran sehingga pelayanan yang berkualitas sangat dituntut untuk memberikan kepuasan kepada mahasiswa. Kualitas pelayanan akan sangat berdampak pada kepuasan dan loyalitas pelanggan, dalam hal ini mahasiswa Fakultas Ilmu Pendidikan(FIP) Universitas Negeri Malang. Hal ini sesuai dengan yang dikemukakan oleh Tjiptono (2012: 153), sebagai berikut: "kualitas, apabila dikelola dengan tepat, berkontribusi positif terhadap terwujudnya kepuasan da loyalitas pelanggan".

Jika pelayanan registrasi administrasi di FIP Universitas Negeri Malang dikatakan berkualitas, maka akan berdampak pada peningkatan kepuasan dan loyalitas mahasiswa FIP bahkan dapat meningkatkan kepercayaan masyarakat pada lembaga pendidikan tersebut. Karena dengan memiliki rasa puas dan loyalitas yang tinggi pada diri mahasiswa maka akan mempengaruhi perilaku positif mahasiswa tersebut serta dapat meyakinkan masyarakat dengan pemikiran yang positif tentang lembaga pendidikan tersebut. Tentunya itu akan bedampak baik pada citra masyarakat terhadap pengelolaan pendidikan di Universitas Negeri Malang khususnya di Fakultas Ilmu Pendidikan.

Berdasarkan uraian tersebut, peneliti tertarik untuk melakukan penelitian dalam rangka untuk mengetahui sejauh mana tingkat kualitas layanan registrasi administrasi yang diberikan oleh Staf akademik Fakultas Ilmu Pendidikan Universitas Negeri Malang kepada mahasiswa.

\section{METODE}

Berdasarkan sifatnya, penelitian ini menggunakan pendekatan kuantitatif dengan desain deskriptif. Penelitian deskriptif adalah "suatu bentuk penelitian yang ditujukan untuk mendeskripsikan fenomenafenomena yang ada, baik fenomena alamiah maupun fenomena buatan manusia. Fenomena itu bisa berupa bentuk, aktivitas, karakteristik, perubahan hubungan, kesamaan, dan perbedaan fenomena antar yang satu dengan fenomena lainnya. Penelitian deskriptif merupakan penelitian yang berusaha mendeskripsikan dan menginterpretasikan sesuatu misalnya kondisi atau hubungan yang ada, pendapat yang berkembang, proses yang sedang berlangsung, akibat atau efek yang terjadi, atau tentang kecenderungan yang sedang berlangsung" (Sukmadinata, 2007: 72). Populasi penelitian ini adalah, mahasiswa di Fakultas Ilmu Pendidikan Universitas Negeri Malang dari tahun angkatan kuliah 2013 sampai tahun 2016. Pemilihan anggota sampel sejumlah 354 mahasiswa menggunakan teknik random sampling diperoleh jumlah 354 mahasiswa. Instrumen pengumpulan data yang digunakan adalah angket yang terdiri dari butir-butir pernyataan berjumlah 40 butir.

\section{HASIL}

Tabel 1 Deskripsi data variabel tingkat kualitas layanan registrasi administrasi di FIP UM

\begin{tabular}{lllll}
\hline No & Rentang skor & Kategori & frekuensi & persentase (\%) \\
\hline 1 & $168-200$ & Sangat Tinggi & 53 & 14.97 \\
2 & $136-167$ & Tinggi & 266 & 75.14 \\
3 & $104-135$ & Sedang & 34 & 9.60 \\
4 & $72-103$ & Rendah & 1 & 0.28 \\
5 & $40-71$ & Sangat Rendah & 0 & 0.00 \\
\hline
\end{tabular}

Berdasarkan Tabel 1 persentase kualitas layanan registrasi administrasi, dapat diartikan bahwa dari 354 orang mahasiswa Fakultas Ilmu Pendidikan Universitas Negeri Malang, sebanyak 53 mahasiswa atau $14,97 \%$ memilihkategori sangat tinggi terhadap pelayanan registrasi administrasi yang telah diberikan oleh pihak fakultas. Sedangkan sebanyak 266 mahasiswa atau setara 75,14\% memilih kategori tingkat kualitas tinggi terhadap pelayanan yang telah diberikan, 34 mahasiswa atau setara 9,60\% memilih kategori tingkat kualitas layanan sedang, 1 mahasiswa atau 0,28\% memilih kategori tingkat kualitas rendah, dan tidak ada yang memilih pada kategori tingkat kualitas layanan sangat rendah. Dari uraian 
tersebut, dapat disimpulkan bahwa dari 354 orang mahasiswa yang menjadi responden tingkat kualitas layanan registrasi administrasi di FIP UM masuk dalam kriteria tinggi.

Tabel 2 Deskripsi Data Kualitas Layananfaktor Kehandalan

\begin{tabular}{lllll}
\hline No & Rentang skor & Kategori & frekuensi & persentase (\%) \\
\hline 1 & $31-35$ & Sangat Tinggi & 29 & 8.19 \\
2 & $25-30$ & Tinggi & 250 & 70.62 \\
3 & $19-24$ & Sedang & 69 & 19.49 \\
4 & $13-18$ & Rendah & 6 & 1.69 \\
5 & $7-12$ & Sangat Rendah & 0 & 0.00 \\
\hline & Jumlah & & 354 & 100 \\
\hline
\end{tabular}

Dari uraian tersebut, dapat disimpulkan bahwa dari 354 orang mahasiswa yang menjadi responden, tingkat kualitas layanan registrasi administrasi faktor kehandalan di FIP UM masuk dalam kriteria tinggi. Kriteria tersebut mengartikan bahwa dari 354 responden mahasiswa hampir seluruhnya memilih jawaban setuju terhadap pernyataan-pernyataan yang tertera pada angket. Adapun faktor kehandalan ini meliputi; ketepatan waktu, kesesuaian dalam penyampaian, dan menjunjung tinggi janji.

Tabel 3 Deskripsi data kualitas layanan faktor daya tanggap

\begin{tabular}{lllll}
\hline No & Rentang skor & Kategori & frekuensi & persentase (\%) \\
\hline 1 & $46-55$ & Sangat Tinggi & 49 & 13.84 \\
2 & $38-45$ & Tinggi & 239 & 67.51 \\
3 & $29-37$ & Sedang & 62 & 17.51 \\
4 & $20-28$ & Rendah & 2 & 0.56 \\
5 & $11-19$ & Sangat Rendah & 2 & 0.56 \\
\hline & Jumlah & & 354 & 100 \\
\hline
\end{tabular}

Dari uraian tersebut, dapat disimpulkan bahwa dari 354 orang mahasiswa yang menjadi responden, tingkat kualitas layanan registrasi administrasi faktor daya tanggap di FIP UM masuk dalam kriteria tinggi. Kriteria tersebut mengartikan bahwa dari 354 responden mahasiswa hampir seluruhnya memilih jawaban setuju terhadap pernyataan-pernyataan yang tertera pada angket.

Adapun faktor daya tanggap ini meliputi;memahami kebutuhan pelanggan, kesigapan dalam menanggapi, aktif dalam kerja, dan kesiapan karyawan untuk memberikan pelayanan/responsif.

Tabel 4 Deskripsi data kualitas layananfaktor jaminan

\begin{tabular}{lllll}
\hline No & Rentang skor & Kategori & frekuensi & persentase (\%) \\
\hline 1 & $26-30$ & Sangat Tinggi & 52 & 14.69 \\
2 & $21-25$ & Tinggi & 275 & 77.68 \\
3 & $16-20$ & Sedang & 24 & 6.78 \\
4 & $11-15$ & Rendah & 3 & 0.85 \\
5 & $6-10$ & Sangat Rendah & 0 & 0.00 \\
\hline & Jumlah & & 354 & 100 \\
\hline
\end{tabular}

Dari uraian tersebut, dapat disimpulkan bahwa dari 354 orang mahasiswa yang menjadi responden, tingkat kualitas layanan registrasi administrasi faktor jaminan. di FIP UM masuk dalam kriteria tinggi. Kriteria tersebut mengartikan bahwa dari 354 responden mahasiswa hampir seluruhnya memilih jawaban setuju terhadap pernyataan-pernyataan yang tertera pada angket. 
Tabel 5 Deskripsi data kualitas layanan faktor empati

\begin{tabular}{lllll}
\hline No & Rentang skor & Kategori & Frekuensi & Persentase (\%) \\
\hline 1 & $31-35$ & Sangat Tinggi & 39 & 11.02 \\
2 & $25-30$ & Tinggi & 222 & 62.71 \\
3 & $19-24$ & Sedang & 89 & 25.14 \\
4 & $13-18$ & Rendah & 3 & 0.85 \\
5 & $7-12$ & Sangat Rendah & 1 & 0.28 \\
\hline & Jumlah & & 354 & 100 \\
\hline
\end{tabular}

Dari uraian tersebut, dapat disimpulkan bahwa dari 354 orang mahasiswa yang menjadi responden, tingkat kualitas layanan registrasi administrasi faktor empati di FIP UM masuk dalam kriteria tinggi. Kriteria tersebut mengartikan bahwa dari 354 responden mahasiswa hampir seluruhnya memilih jawaban setuju terhadap pernyataan-pernyataan yang tertera pada angket.

Tabel 6 Deskripsi data kualitas layanan faktor bukti fisik

\begin{tabular}{lllll}
\hline No & Rentang skor & Kategori & Frekuensi & Persentase (\%) \\
\hline 1 & $37-45$ & Sangat Tinggi & 50 & 14.12 \\
2 & $30-36$ & Tinggi & 268 & 75.71 \\
3 & $23-29$ & Sedang & 35 & 9.89 \\
4 & $16-22$ & Rendah & 1 & 0.28 \\
5 & $9-15$ & Sangat Rendah & 0 & 0.00 \\
\hline & Jumlah & & 354 & 100 \\
\hline
\end{tabular}

Dari uraian tersebut, dapat disimpulkan bahwa dari 354 orang mahasiswa yang menjadi responden, tingkat kualitas layanan registrasi administrasi faktor bukti fisik di FIP UM masuk dalam kriteria tinggi. Kriteria tersebut mengartikan bahwa dari 354 responden mahasiswa hampir seluruhnya memilih jawaban setuju terhadap pernyataan-pernyataan yang tertera pada angket.

\section{PEMBAHASAN}

\section{Kualitas Layanan Registrasi Administrasi di Fakultas Ilmu Pendidikan Universitas Negeri Malang}

Kualitas pelayanan dapat didefinisikan sebagai seberapa jauh perbedaan antara kenyataan dan harapan para pelanggan atas layanan yang terima. Kualitas pelayanan dapat diketahui dengan cara membandingkan persepsi para pelanggan atas layanan yang benar-benar mereka terima. Kotler (2005:153) menyatakan kualitas layanan adalah model yang menggambarkan kondisi pelanggan dalam bentuk harapan akan layanan dari pengalaman masa lalu, promosi dari mulut ke mulut, dan iklan dengan membandingkan pelayanan yang mereka harapkan dengan apa yang mereka terima/rasakan. Kualitas pelayanan adalah tingkat keunggulan yang diharapkan dan pengendalian atas tingkat keunggulan tersebut untuk memenuhi keinginan pelanggan. (Nasution 2004:47).

Berdasarkan hasil analisis pada penelitian ini, mengungkapkan bahwa kualitas layanan registrasi administrasi yang telah diberikan pihak Fakultas Ilmu Pendidikan Universitas Negeri Malang sebagai penyedia layanan tersebut berada pada kategori tinggi. Hasil penelitian menunjukkan, bahwa dari 354 mahasiswa sebagai responden sebanyak 266 mahasiswa atau setara 75,14\% memilih tingkat kualitas yang tinggi. Hal ini berarti layanan registrasi administrasi yang telah diberikan dalam bentuk produk atau jasa sudah memenuhi harapan mahasiswa sebagai pelanggan. 


\section{Dimensi atau Faktor-Faktor Kualitas Layanan Registrasi Administrasi di Fakultas Ilmu Pendidikan Universitas Negeri Malang}

Pada penenlitian ini, peneliti melakukakan pengukuran terhadap tingkat kualitas layanan jasa staf akademik dengan memberikan penilaian terhadap setiap dimensi atau faktor-faktor yang menentukan kualitas layanan produk atau jasa. Dimensi atau faktor-faktor tersebut meliputi Keandalan (Reliability), Daya Tanggap (Responsivness), Empati (Emphaty), Jaminan (Assurance), dan Bukti Fisik (Tangibles). Melalui dimensi-dimensi ini nantinya akan diketahui seberapa tinggi kualitas layanan registrasi administrasi yang telah diberikan sudah.

\section{Keandalan (Reliability)}

Keandalan menurut Parasuraman dalam Lupiyoadi (2001:145), yaitu kemampuan perusahaan untuk memberikan pelayanan sesuasi yang dijanjikan secara akurat dan terpercaya. Sub-variabel Keandalan dalam penelitian ini memilih tiga inidikator yaitu ketepatan waktu, kesesuaian dalam penyampaian, dan menjunjung tinggi janji.

Berdasarkan hasil analisis, menunjukkan bahwa dari 354 mahasiswa sebagai responden sebanyak 29 responden memilih tingkat kualitas sangat tinggi terhadap faktor keandalan pada layanan registrasi administrasi di FIP UM, 250 responden memilih tingkat kualitas tinggi terhadap faktor keandalan pada layanan registrasi administrasi di FIP UM, 69 responden memilih tingkat kualitas sedang terhadap faktor keandalan pada layanan registrasi administrasi di FIP UM, , dan 6 responden memilih tingkat kualitas rendah terhadap faktor keandalan pada layanan registrasi administrasi di FIP UM. Hasil Penelitian tersebut menunjukkan bahwa ada pelaksanaan yang baik dari staf akademik terhadap faktor kehandalan ini, seperti tepat saat memulai dan mengakhiri jam kerja, atau tepat waktu dalam menyelesaikan kebutuhan mahasiswa sesuai dengan kesepakatan waktu yang ditetapkan.

\section{Daya Tanggap (Responsivness)}

Menurut Kotler (dalam Sari, 2003: 80) yang menyatakan daya tanggap adalah kemauan untuk membantu pelanggan dan memberikan jasa dengan cepat atau dan bermakna serta kesediaan mendengar dan mengatasi keluhan pelanggan. Sub-variabel Keandalan dalam penelitian ini memilih tiga indikator yaitu memahami kebutuhan pelanggan, kesigapan dalam menanggapi, aktif dalam bekerja, dan kesiapan karyawan untuk memberikan pelayanan/responsive.

Berdasarkan penlitian yang telah dilakukan pada responden dan setelah dianalisis, tingkat kualitas terhadap penerapan sub-variabel daya tanggap dalam layanan registrasi administrasi di FIP UM berada pada kriteria tinggi. Hal tersebut terbukti dari penilaian responden yang rata-rata memilih altenatif jawaban setuju terhadap pernyataan-pernyataan yang tersedia di angket. Secara rinci hasil penelitian tersebut yaitu dari 354 responden, 49 responden memilih tingkat kualitas sangat tinggi, 239 responden memilih tingkat kualitas tinggi, 62 responden memilki tingkat kualitas sedang, 2 responden memilki tingkat kualitas rendah, dan 2 responden memilih tingkat kualitas sangat rendah. Hasil tersebut meninjukkan bahwa staf akademik sudah melaksanakan aspek daya dengan baik misalnya aktif dan responsive dalam bekerja serta cepat dan sigap dalam menangani kebutuhan mahasiswa. Hal itu yang memberikan mahasiswa rasa puas terhadap layanan yang telah diberikan.

\section{Jaminan (Assurance)}

Menurut Parasuraman (dalam Lupiyoadi, 2001: 149) menyatakan bahwa pengetahuan, kesopansantunan, dan kemampuan para pegawai perusahaan untuk menumbuhkan rasa percaya para pelanggan kepada perusahaan. Sub-variabel Keandalan dalam penelitian ini memilih tiga indikator yaitu keterampilan karyawan, pengetahuan karyawan terhadap kebutuhan pelanggan, dan ketepatan dalam memberikan informasi.

Berdasarkan penlitian yang telah dilakukan pada responden dan setelah dianalisis, tingkat kualitas penerapan sub-variabel jaminan dalam layanan registrasi administrasi di FIP UM berada pada kriteria tinggi. Hal tersebut terbukti dari penilaian responden yang rata-rata memilih altenatif jawaban setuju terhadap pernyataan-pernyataan yang tersedia di angket. Secara rinci hasil penelitian tersebut yaitu dari 
354 responden, 52 responden memilih tingkat kualitas sangat tinggi, 275 responden memilih tingkat kualitas tinggi, 24 responden memilih tingkat kualitas sedang, dan 3 responden memilih tingkat kualitas rendah. Dari hasil tersebut, dapat dikatakan bahwa staf/petugas layanan registrasi administrasi di FIP UM memberikan jaminan yang baik kepada setiap mahasiswa yang memilih keperluan. Hasil tersebut juga menunjukkan bahwa staf akademik sudah tepat melaksanakan tugasnya yakni terampil dan tepat dalam melayani kebutuhan sehingga timbul rasa percaya dari mahasiswa.

\section{Empati (Emphaty)}

Sub-variabel Keandalan dalam penelitian ini memilih tiga indikator yaitu kepedulian terhadap pelanggan dan mengerti kebutuhan dan keinginan pelanggan. Sesuai dengan apa yang dikatakan Parasuraman (dalam Lupiyoadi, 2001: 146) bahwa memberikan perhatian yang tulus dan bersifat individual atau pribadi yang diberikan kepada para pelanggan dengan berupaya memahami keinginan konsumen.

Berdasarkan penlitian yang telah dilakukan pada responden dan setelah dianalisis, tingkat kualitas penerapan sub-variabel empati dalam layanan registrasi administrasi di FIP UM berada pada kriteria tinggi. Hal tersebut terbukti dari penilaian responden yang rata-rata memilih altenatif jawaban setuju terhadap pernyataan-pernyataan yang tersedia di angket. Secara rinci hasil penelitian tersebut yaitu dari 354 responden, 39 responden memilih tingkat kualitas sangat tinggi, 222 responden memilih tingkat kualitas tinggi, 89 responden memilki tingkat kualitas sedang, 3 responden memilki tingkat kualitas rendah,dan 1 responden memilih tingkat kualitas sangat rendah. Dari hasil tersebut, dapat dikatakan bahwa petugas layanan registrasi administrasi di FIP UM memilih empati atau peduli dan memahami dengan baik kebutuhan setiap mahasiswa.

\section{Bukti Fisik (Tangibles)}

Sub-variabel Keandalan dalam penelitian ini memilih tiga indikator yaitu fasilitas, sarana, dan prasarana, suasana tempat, penampilan karyawan, dan peralatan yang digunakan untuk melayani konsumen. Helien (dalam Sari, 2013: 77) menyatakan bahwa elemen-elemen tidak nyata lebih sulit diukur dan sering kali subjektif.

Berdasarkan penelitian yang telah dilakukan pada responden dan setelah dianalisis, tingkat kualitas penerapan sub-variabel bukti fisik dalam layanan registrasi administrasi di FIP UM berada pada kriteria tinggi. Hal tersebut terbukti dari penilaian responden yang rata-rata memilih alternatif jawaban setuju terhadap pernyataan-pernyataan yang tersedia di angket. Secara rinci hasil penelitian tersebut yaitu dari 354 responden, 50 responden memilih tingkat kualitas sangat tinggi, 268 responden memilih tingkat kualitas tinggi, 35 responden memiliki tingkat kualitas sedang, dan 1 responden memiliki tingkat kualitas rendah. Dari hasil tersebut, dapat dikatakan bahwa petugas layanan registrasi administrasi di FIP UM memilih sarana dan prasarana pendukung yang memadai dalam melakukan pelayanan sehingga dapat memperlancar segala aktivitas yang menjadi kebutuhan mahasiswa.

\section{KESIMPULAN DAN SARAN}

\section{Kesimpulan}

Berdasarkan hasil penelitian dan pembahasan yang telah diuraikan peneliti sebelumnya, dapat ditarik kesimpulan sebagai berikut: Tingkat kualitas layanan registrasi administrasi di Fakultas Ilmu Pendidikan Universitas Negeri Malang berada pada kategori tinggi. Hal ini dibuktikan dari hasil analisis sub variabel kualitas layanan yaitu keandalan, daya tanggap, jaminan, empati, dan bukti fisik yang secara keseluruhan setiap sub variabel memiliki persentase yang berada pada kategori tinggi. Berdasarkan hasil analisis tersebut, peneliti dapat menyimpulkan bahwa kualitas layanan registrasi administrasi di FIP UM berada pada kategori tinggi. Hal tersebut berarti staf akademik sudah memenuhi standar kualitas pelayanan yang ditetapkan dan diinginkan oleh lembaga terkait. 


\section{Saran}

Berdasarkan kesimpulan dari penelitian ini, saran yang dapat diberikan oleh peneliti sebagai berikut: (1) Bagi Dekan Fakultas Ilmu Pendidikan, penelitian ini diharapkan bisa menjadi gambaran tingkat kualitas kinerja staf akademik Fakultas Ilmu Pendidikanserta menjadi masukan atau tolak ukur bagi pimpinan dalam melakukan proses pengawasan dan evaluasi pada bidang yang terkait dalam rangka menigkatkan mutu atau kulaitas layanan registrasi administrasi di FIP UM; (2) Bagi Staf Akademik FIP, penelitian ini diharapkan berguna bagi staf akademik dalam meningkatkan kualitas kinerjanya agar sesuai dengan standar kualitas yang diinginkan dengan mengutamakan mutu layanan serta mampu melakukan evalusi terhadap layanan registrasi administrasi yang diberikan; (3) Bagi Peneliti Lain, penelitian ini diharapkan dapat menjadi sumbangan pikiran atau bahan rujukan bagi peneliti lain dalam mengembangkan dan melakukan penelitian dengan topik yang terkait. Peneliti lain juga disarankan untuk melakukan pengembangan dengan menghubungkan dengan variabel lain sehingga mendapat hasil yang lebih proporsional. Bagi Mahasiswa Penelitian ini diharapkan berguna bagi mahasiswa sebagai sarana untuk penyampaian harapan serta sebagai bentuk evaluasi terhadap layanan registrasi administrasi di Fakultas Ilmu Pendidikan Universitas Negeri Malang.

\section{DAFTAR RUJUKAN}

Burhanuddin, 2016. Perilaku Organisasi dalam Manajemen dan Kepemimpinan. Malang: Universitas Negeri Malang.

Chrisyanti, I. 2011. Manajemen Perkantoran. Jakarta: PT Prestasi Pustakaraya.

Kotler, Philip. 2005. Manajemen Pemasaran. Jilid 1. Edisi Kesebelas. PT. Indeks, Jakarta.

Lupiyoadi, R. 2001. Manajemen Pemasaran Jasa: Teori dan Praktek. Jakarta: Salemba Empat.

Nasution, M.N. 2004. Manajemen Mutu Terpadu. Jakarta:Ghalia Indonesia.

Ratminto\&Atik S.W. 2009. Manajemen Pelayanan: Pengembangan Model Konseptual, Penerapan Citizen's Cahrter dan Standar Pelayanan Minimal. Yogyakarta: Pustaka Pelajar.

Sari, R.P.2013. Pengaruh kualitas layanan Terhadap Kepuasan Peserta Pendidikan dan Pelatihan Di Badan Penelitian Pengembangan Dan Penndidikan Dan Pelatihan Kabupaten Pasuruan. Skripsi. Administrasi Pendidikan Universitas Negeri Malng.

Susanto, H. 2014. Pengaruh Layanan registrasi administrasi Terhadap Kepuasan Mahasiswa Pascasarjana Universitas terbuka Pada Unit Program Belajar Jarak Jauh (UPBJJ) Mataram. (online),(http://jurnal.ut.ac.id// JPTJJ/article/download/82/76), diakses 10 Maret 2017. 